\title{
PENGEMBANGAN MATERI AJAR BERBANTUAN EDMODO PADA MATA PELAJARAN GAMBAR TEKNIK MANUFAKTUR UNTUK SMK
}

\author{
Ervin Priambodo ${ }^{1}$, Apri Nuryanto ${ }^{2}$ \\ Pendidikan Teknik Mesin Fakultas Teknik Universitas Negeri Yogyakarta \\ Email: ervinep87@gmail.com
}

\begin{abstract}
This study aims to determine the process of developing Edmodo-assisted teaching materials and determine the level of eligibility in learning Manufacturing Engineering Drawings subject. The research type is Research and Development methods (R\&D), using the 4D model, which consists of four steps, namely defining, design, development, and disseminating. The subjects of this study were 30 students of SMK N 2 Yogyakarta majoring in Machining. Data collection techniques are done by observation, interviews, and questionnaires. The initial analysis was done descriptively, while the feasibility data analysis was carried out quantitatively. The quantitative data were subsequently converted into qualitative data. These development results are (1) Edmondoassisted teaching material products in Manufacturing Engineering Drawing (GTM) subjects with the flip builder application's help. The learning material is divided into five learning activities: drawing 2D sketches, making 3D drawings, editing 3D models, assembling 3D models (assembly), and making working drawings. (2) The feasibility of teaching materials and the media used is determined from the experts' validation results, with the results of the validation of the material experts $82 \%$ and $83.65 \%$ media experts, which are in the very feasible criteria. The revised product is then tested on students through online trials, with $83.105 \%$ results are in the very feasible category. In conclusion, the Edmodo-assisted teaching materials on Manufacturing Engineering Drawing subjects for Vocational Schools are very suitable for use in learning.
\end{abstract}

Keywords: Research and Development, Teaching Materials, Manufacturing Engineering Drawings

\begin{abstract}
ABSTRAK
Penelitian ini bertujuan untuk mengetahui proses pengembangan materi ajar berbantuan Edmodo dan mengetahui tingkat kelayakannya untuk diterapkan dalam pembelajaran Gambar Teknik Manufaktur (GTM). Jenis penelitian ini mengunakan metode penelitian dan pengembangan (Research \& Development) dengan menggunakan model 4D yang terdiri dari empat langkah yaitu pendefinisian (define), perancangan (design), pengembangan (development), dan penyebarluasan (disseminate). Subjek penelitian ini adalah siswa SMK N 2 Yogyakarta jurusan Pemesinan kelas XII yang berjumlah 30 siswa. Teknik pengumpulan data dilakukan dengan observasi, wawancara, dan angket. Analisis awal dilakukan secara deskriptif, sedangkan analisis data kelayakan dilakaukan secara kuantitatif yang dikonversi ke dalam data kualitatif. Hasil pengembangan ini disampaikan sebagai berikut. (1) Produk materi ajar berbantuan Edmodo pada mata pelajaran GTM dengan bantuan aplikasi flip builder terbagi dalam 5 kegiatan pembelajaran, yaitu: menggambar sketch 2D, membuat gambar 3D, mengedit model 3D, merakit model 3D (assembly), dan membuat gambar kerja. (2) Kelayakan materi ajar dan media berdasarkan hasil validasi ahli materi $82 \%$ dan ahli media $83,65 \%$ sehingga termasuk pada kriteria sangat layak. Produk yang telah direvisi kemudian diujikan kepada siswa melalui uji coba secara online dengan hasil 83,105\% yang termasuk dalam kategori sangat layak. Dengan demikian, ateri ajar berbatuan Edmodo pada mata pelajaran Gambar Teknik Manufaktur untuk SMK sangat layak digunakan dalam pembelajaran.
\end{abstract}

Kata kunci: Penelitian dan Pengembangan, Materi ajar, Gambar Teknik Manufaktur

\section{PENDAHULUAN}

Perkembangan teknologi pada zaman sekarang memiliki peran yang sangat penting dalam kehidupan manusia. Pemanfaatan teknologi pada dasarnya bertujuan untuk meningkatkan dan mempermudah pekerjaan manusai dalam kehidupan sehari-hari. Perkembangan teknologi digital selalu mempunyai peran yang sangat signifikan dalam dunia Pendidikan. Upaya pemerintah dalam menunjang hal tersebut salah satunya dengan mengadakan ISODEL (Internasional Symposium on Open, Distance and E-Learning) 
pada tahun 2018 yang dilaksanakan di Bali yang membahas "Pendidikan 4.0 untuk Indonesia. Beberapa materi yang dibahas mengenai proses dan model belajar yang di terapkan dalam era Pendidikan 4.0 yaitu dengan model bermain, belajar dan bekerja terjadi di dalam waktu yang sama, kemudian mengenal gamifikasi, ecommerce, virtual, dan belajar dari dunia maya. Sesuai dengan Peraturan Menteri Pendidikan dan Kebudayaan Republik Indonesia nomor 65 tahun 2013 yang menyatakan bahwa proses pembelajaran pada satuan pendidikan diselengggarakan secara intraktif, inspiratif, menyenangkan, menantang, memotivasi peserta didik untuk aktif serta memberikan ruang yang cukup bagi prakarsa, kreativitas dan kemandirian sesuai dengan bakat, minat, dan perkembangan fisik serta psikologis peserta didik. Suroto (2015: 318) menjelaskan bahwa pembelajaran merupakan kegiatan melaksanakan kurikulum pendidikan untuk memberikan pengaruh kepada siswa dalam mencapai kompetensi pembelajaran.

Berhubungan dengan kurikulum, UU Nomor 20 tahun 2003 tentang sistem Pendidikan Nasional menyebutkan bahea kurikulum adalah seperangkat rencana dan pengaturan mengenai tujuan, isi, dan bahan pelajaran serta cara yang digunakan sebagai pedoman penyelenggaraan kegiatan pembelajaran untuk mencapai tujuan pendidikan tertentu.

Tuntunan kompetensi CAD (Computer Aided Design) yang semakin tinggi di dunia industri, tentu harus sejalan dengan pembentukan tenaga kerja yang terampil dan kompeten oleh karena itu, SMK dirancang untuk mempersiapkan generasi yang mandiri dan siap bekerja di dunia industri dengan bekal pengetahuan dan kemampuan agar hidup mandiri (Febrianto dan Yatin, 2017: 74). Berdasarkan hasil observasi yang dilakukan di SMK N 2 Yogyakarta menunjukan bahwa kompetensi CAD peserta didik belum memenuhi kompetensi yang diharapkan oleh sekolah. Kompetensi yang belum memenuhi standart dapat berdampak pada rendahnya tingkat keserapan lulusan untuk menjadi tenaga kerja di dunia industri, sehingga tujuan utama dari SMK yaitu untuk mempersiapkan tenaga kerja yang terapil tidak dapat tercapai.

Menurut Paryanto dan Asnawi (2012: 86) permasalahan-permasalahan yang timbul dalam pembelajaran memerlukan upaya serius dalam penanganan agar pembelajaran yang berkualitas dapat tercapai.

Pengembangan materi pembelajaran merupakan salah satu bentuk meningkatkan keterampilan dan kompetensi yang dimiliki oleh peserta didik untuk membentuk tenaga kerja yang siap di dunia industri. Menurut Ibrahim dan Nana Syaodih (2002), materi pembelajaran merupakan suatu yang disajikan guru untuk diolah kemudian dipahami oleh siswa dalam rangka pencapaian tujuan-tujuan intruksional yang telah ditetapkan.

Penggunaan media pembelajaran juga penting dalam proses pembelajaran, karena media pembelajaran dapat dijadikan alat untuk menyampaiakan informasi untuk merangsang pikiran, membangkitkan semangat, perhatian, serta kemauan siswa sehingga peserta didik dapat memperoleh pengetahuan dan keterampilan sesuai informasi yang di sampaikan. Penggunaan media pembelajaran yang tepat dan bervariasi dapat meningkatkan semangat belajar siswa, dan juga siswa dapat memahami pesan yang disampaikan oleh guru dengan baik

Edmodo merupakan social network berbasis lingkungan sekolah yang dikembangkan oleh Nicolas Borg dan Jeff O’Hara. Edmodo merupakan jejaring sosial untuk pembelajaran berbasis Learning Managent System (LMS). Edmodo ini dapat digunakan sebagai media pembelajaran yang sesuai dengan kurikulum 2013. Edmodo memiliki kelebihan bila dibandingkan dengan media sosial Learning Management System lainnya. Fitur yang terdapat di dalamnya dapat dimanfaatkan guru sebagai alat penyampaian pesan/ informasi ke peserta didik, serta kelebihan lain dari aplikasi jejaring sosial ini dapat diakses bebas di www.edmodo.com oleh guru, siswa, maupun orang tua siswa. 
Berdasarkan uraian di atas maka peneliti mengembangkan materi ajar dengan berbantuan Edmodo sebagai media pembelajaran pada materi pelajaran Gambar Teknik Mnufaktur, untuk membantu peserta didik meningkatkan kompetensi dan kualitas pembelajaran dapat meningkat.

\section{METODE}

Jenis penelitian yang digunakan adalah Penelitian dan Pengembangan dengan model pengembangannya 4D (four $D$ ) yang terdiri dari Pendefinisian (Define), Perancangan (Design), Pengembangan (Develop), dan Penyebarluasan (Disseminate) (Thiagarajan, 1974: 5).

Penelitian ini dilaksanakan di SMK N 2 Yogyakarta di N 2 Yogyakarta, Jl. A.M. Sangaji No.47, Cokrodiningratan, Kec. Jetis, Kota Yogyakarta, Daerah Istimewa Yogyakarta 55233. Waktu pelaksanaan penelitian dilakukan pada semester genap tahun ajaran 2020 (MaretMei 2020).

Target/subjek penelitian ini adalah ahli materi, ahli media, dan siswa kelas XII Jurusan Teknik Pemesinan SMK N 2 Yogyakarta. Ahli materi merupakan 1 orang dosen Pendidikan Teknik Mesin FT UNY .Ahli media merupakan 1 orang dosen Pendidikan Teknik Mesin FT UNY. Peserta didik sebagai responden sejumlah 30 siswa. Prosedur pengembangan model 4-D dapat dilihat dalam Gambar 1 (Thiagaradjan, 1974: 5).

Tahap pertama yang dilakukan adalah pengidentifikasian (define). tahap pendefinisisan dilakukan untuk menetapkan dan mendefinisikan syarat-syarat pengembangan. Konteks pengembangan materi pelajaran atau bahan ajar pada tahap ini dilakukan dengan cara 1) analisis kurikulum, 2) analisis karakter siswa, 3) analisis materi, 4) merumuskan tujuan. Tahap kedua yang dilakukan adalah perancangan (design). Kegiatan yang dilakukan adalah menyusun tes kriteria, memilih media pembelajaran, pemilihan bentuk penyajian, mensimulasikan penyajian materi. Tahap ketiga adalah pengembangan (develop). Pada tahap ini dilakukan pengujian isi dari materi dan media yang akan diajarkan ke siswa kepada pakar atau validator dan juga peserta didik yang akan menggunakan. Tahap keempat yang dilakukan adalah penyebarluasan (disseminate). Pada tahap ini, materi ajar akan disebarluaskan kepada guru dan siswa di jurusan Teknik Pemesinan SMK N 2 Yogyakarta.

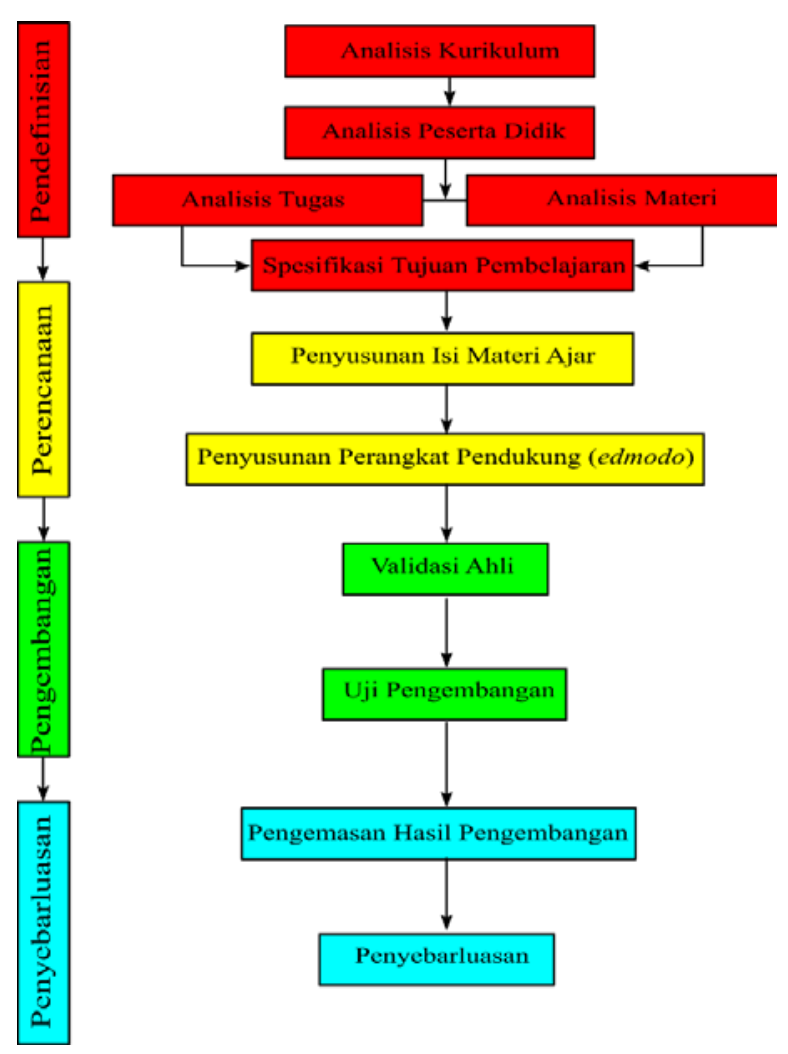

Gambar 1. Prosedur Pengembangan Model 4D

Teknik pengumpulan data yang digunakan adalah wawancara dan kuesioner. Wawancara dilakukan kepada guru Gambar Teknik Manufaktur SMK N 2 Yogyakarta. Wawancara dilakukan secara online untuk mengetahui kurikulum, tujuan pembelajaran, materi yang ditekankan pada pembelajaran, dan permasalahan yang terjadi saat pembelajaran. Sedangkan, kuesioner digunakan untuk validasi ahli materi dan ahli media, serta respon peserta didik teradap produk.

Instrumen yang digunakan dalam penelitian ini berupa angket. Instrumen bersifat tertutup dalam bentk check list. Responden hanya menjawab dengan cara memberi tanda 
chek $(\sqrt{ })$ pada alternative jawaban ang tersedia. Pengambilan data berupa angket diberikan kepada responden yang terdiri dari ahli materi, ahli media, dan peserta didik sebagai pengguna. Angket validasi yang akan digunakan dalam meberikan nilai materi dan media yang disusun berdasarkan skala lajuan dengan skala (rating skale) 1 sampai dengan 4 .

Tabel 1. Skala Lajuan (Rating Scale)

\begin{tabular}{cc}
\hline Keteangan Pilihan & Skala \\
\hline Sangat baik & 4 \\
Baik & 3 \\
Tidak Baik & 2 \\
Sangat Tidak Baik & 1 \\
\hline
\end{tabular}

Angket respon peserta didik digunakan dalam bentuk angket dnengan tujuan untuk mengetahui keefektifan daan kepraktisan produk, serta menampung saran serta komentar selama pembelajaran. Angket disusun dengan skala penilaian berupa skala kualitatif, yang kemudian data yang diperoleh diubah dalam data kuantitatif berasarkan skala likert.

Tabel 2. Skala Likert

\begin{tabular}{cc}
\hline Keteangan Pilihan & Skala \\
\hline Sangat baik & 5 \\
Baik & 4 \\
Cukup & 3 \\
Kurang & 2 \\
Sangat Kurang & 1 \\
\hline
\end{tabular}

Teknik analisa data yang digunakan dalam menganalisis data hasil wawancara dan observasi adalah deskriptif kualitatif data yang di peroleh kemudian dijabarkan, sedangkan teknk analisis data yang digunakan pada penilaian ahli materi dan ahli media adalah menghitung skor rerata yang ada pada masing masing aspek dan skor rerata jawaban keseluruhan tanpa mengesampingkan validitas dan reabilitasnya. Skor rata-rata yang diperoleh dari perhitungan dikonversi menjadi tingkay kelayakan produk secara kualitatif dan disesuaikan dengan tabel klasifikasi. Tabel klasifikasi disusun berdasarkan skor tertinggi, skor terendah, jumlah kelas, dan jarak interval Wdoyoko, 2012. Berdasarkan perhiyungan diperoleh bahwa table klasifikasi memiliki jarak interval 0,75 yang ditabulasikan pada Tabel 3 .

Tabel 3. Kalsifikasi Tingkat Kelayakan Ahli

\begin{tabular}{cc}
\hline Rentang Skor & Kategori \\
\hline $3,25<\bar{x} \leq 4$ & Sangat Layak \\
$2,5<\bar{x} \leq 3,25$ & Layak \\
$1,75<\bar{x} \leq 2,5$ & Tidak Layak \\
$1 \leq \bar{x} \leq 1,75$ & Sangat Tidak Layak \\
\hline
\end{tabular}

Analisis data angket respon peserta didik dilakukan setelah instrument angket diuji validitas dan reliabilitas dengan mencari indeks Cronbanch's Alpha dan indeks tingkat korelasi

Tabel 4. Kalsifikasi Tingkat Kelayakan Ahli

\begin{tabular}{cc}
\hline Rentang Skor & Kategori \\
\hline$>4,2$ & Sangat baik \\
$>3,4 \mathrm{~s} / \mathrm{d} 4,2$ & Baik \\
$>2,6 \mathrm{~s} / \mathrm{d} \mathrm{3,4}$ & Cukup \\
$>1,8 \mathrm{~s} / \mathrm{d} \mathrm{2,6}$ & Kurang \\
$\leq 1,8$ & Sangat kurang \\
\hline
\end{tabular}

Tahap selanjutnya setelah data terkumpul dilakuakan analisis dengan analisis deskriptif kuantitatif yang disajikan dalam distribusi skor dan presentase terhadap kategori dengan skala penilaian yang telah ditentukan. Adapun pembagian kriteria kelayakan daoat dilihat pada Tabel 5.

Tabel 5. Penilaian Kelayakan (Arikunto,2009)

\begin{tabular}{cc}
\hline Presentase & Interprestasi \\
Kelayakan & \\
\hline $81 \%-100 \%$ & Sangat Layak \\
$61 \%-80 \%$ & Layak \\
$41 \%-60 \%$ & Cukup \\
$21 \%-40 \%$ & Kurang Layak \\
$0 \%-20 \%$ & Tidak layak \\
\hline
\end{tabular}

\section{HASIL DAN PEMBAHASAN}

Hasil penelitian dan pengembangan yang telah dilakukan adalah produk materi ajar 
berbantuan Edmodo pada mata pelajaran Gambar Teknik Mnufaktur untuk SMK yang dikembangkan dengan aplikasi tambahan Flip Builder untuk membuat tampilan materi ajar lebih menarik. Materi yang dibuat dalam pembelajaran Gambar Teknik Manufaktur terdiri dari 5 kegiatan pembelajaran yang embahas tentang penggunaan aplikas CAD, yaitu Autodesk Inventor Profesional 2017 (Tabel 6), dimana setiap kegiatan pembelajaran memuat judul bab, tujuan pembelajaran, isi materi, ringkasam, serta evaluasi praktik, sedangkan untuk latihan soal peserta didik dapat mengakses menggunakan media pembelajaran Edmodo. Penggunaan materi ajar dalam pembelajaran menggunakan platform Edmodo sebagai media untuk membantu guru dalam memberikan materi ke peserta didik. Materi ajar dapat dibuka secara online melalui link yang telah dibuat di Flip builder.

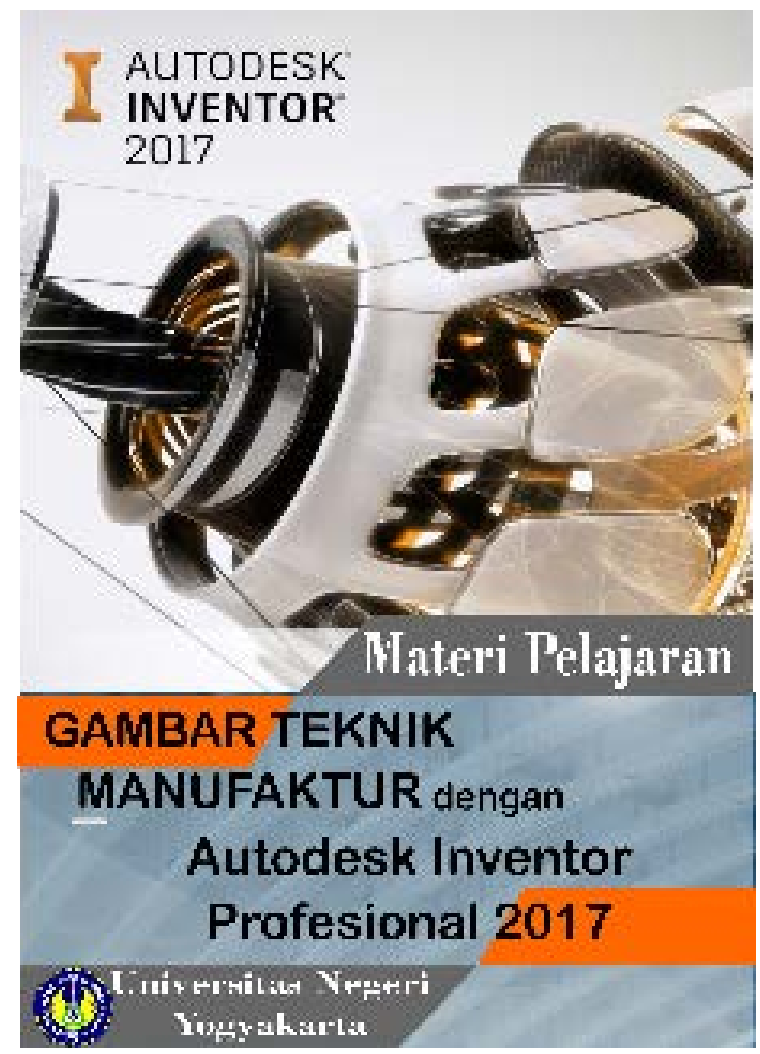

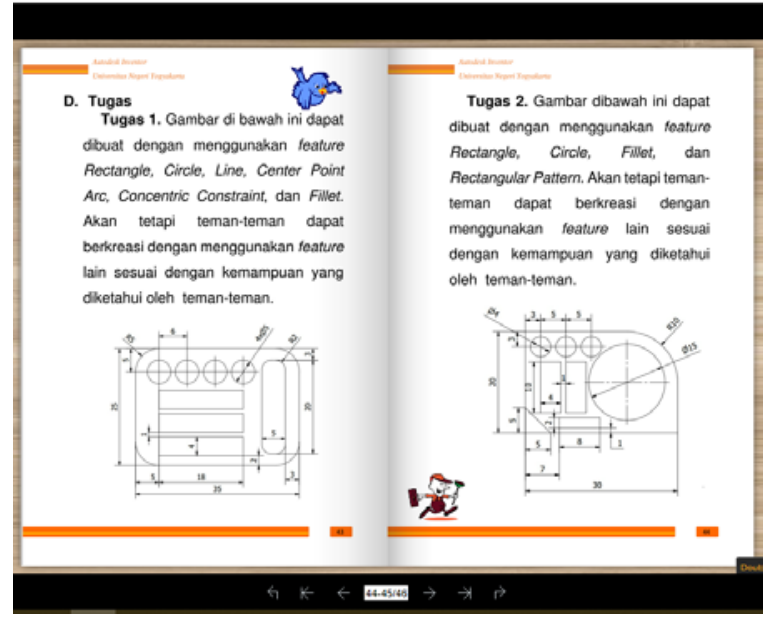

Gambar 3. Contoh Evaluasi Praktek

Materi yang disampaikan kepada peserta didik berasal dari kompetensi dasar gambar Teknik Manufaktur sesuai dengan kurikulum 2013. Materi disusun sesuai dengan umur peserta didik yang sedang memasuki tahap operasional formal dengan ciri dapat berpikir secra konseptual dan berpikir secra hipotesis sehingga peseta didik dapat membangun pemikiran sendiri sesuai dengan hal yang diterima. Sehingga materi ajar disajikan dengan menggunakan media yang dikembangkan sehingga mampu mengembangkan rasa ingin tau peserta didik, dengan memberikan kesempatan pada peserta didik untuk lebih mendalami dan lebih mengeksplorasi materi secara mandiri, dengan bantuan guru sebagai fasilitator.

Tabel 6. Materi Kegiatan Pembelajaran

\begin{tabular}{|c|c|c|}
\hline $\begin{array}{c}\text { Kegiatan } \\
\text { Pembelajaran }\end{array}$ & Materi & \\
\hline 1 & Menggambar Sketch 2D & \\
\hline 2 & Membuat Model 3D & \\
\hline 3 & Mengedit Model 3D & \\
\hline 4 & $\begin{array}{ll}\text { Merakit } & \text { Model } \\
\text { (Assembly) } & \end{array}$ & \\
\hline 5 & Membuat Gambar Kerja & \\
\hline
\end{tabular}

Gambar 2. Desain Sampul Depan 


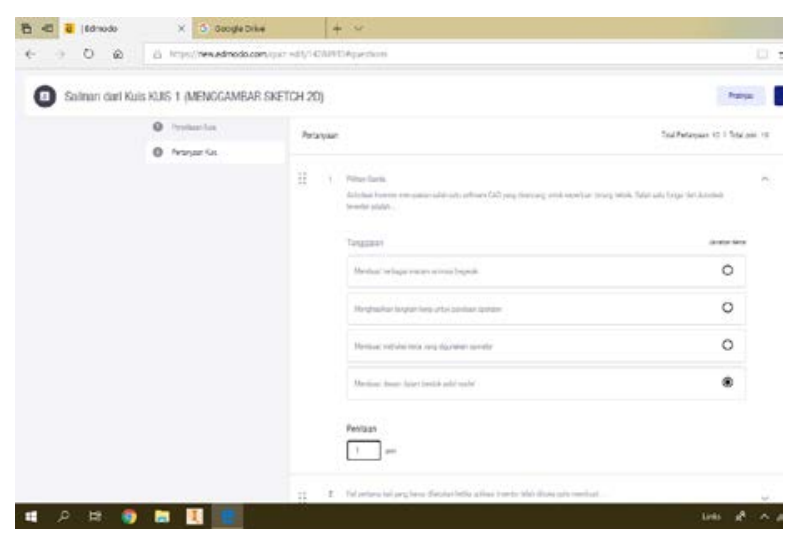

Gambar 4. Contoh Latihan Soal

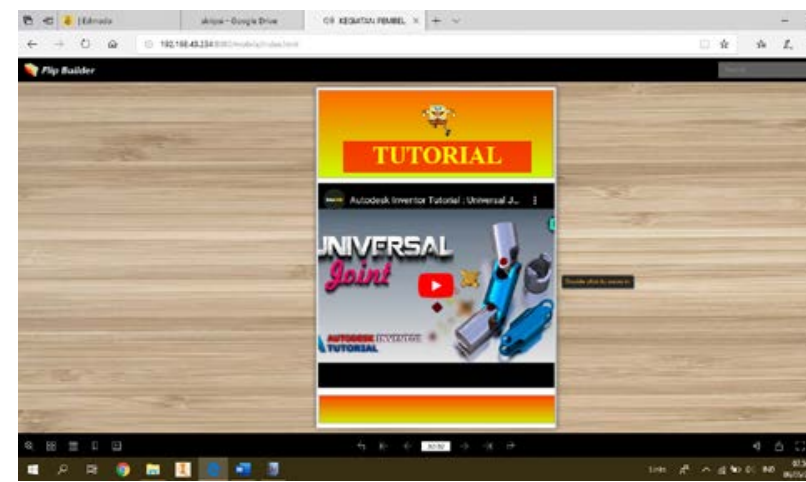

Gambar 7. Video yang disematkan pada materi

Pengembangan materi ajar GTM dengan berbantuan Edmodo sebagai media pembelajaran serta Flip builder untuk membuat tampian lebih menarik, dilakukan dalam empat tahapan, tahap pertama yaitu tahap pendefinisian (define) pada tahap ini dilakukan analisis berupa analisis kurikuum, analisis karater siswa, dan analisis materi untuk mengetahui dan menentukan tujuan pembelajaran yang akan dicapai oleh peserta didik.

Tahapan kedua yaitu perancangan (design). Kegiatan yang dilakukan adalah peyusunan parameter penilaian, pemilihan format, pemilihan media dan rancangan awal dari materi. Kegiatan yang dilakukan pada penyusunan parameter penilaian adalah pembuatan angket penilaian untuk menilai materi dan media yang dilakukan oleh ahli materi dan media serta angket respon peserta didik. Kegiatan yang dilakukan pada setelah penyusunan parameter penilaian adalah pemilihan format materi ajar disesuaikan dengan hasil analisa yang sebelumnya dilakukan, kemudia dilanjutkan dnegan pemilihan media pembelajaran yang akan digunakan. Dalam penelitian ini materi ajar dikembangkan menggunkan 2 media pembelajaran Edmodo dan Flip builder.

Materi ajar yang telah tersusun kemudian masuk ke tahap pengembangan (development) yang kemudian menghasilkan produ akhir. Produk kemudian divalidasi oleh ahli materi dan ahli media. Validasi ahli materi dilakukan oleh dosen Pendidikan Teknik Mesin FT UNY.

Hasil validasi dari dosen ahli materi dapat dilihat pada Tabel 8 .

Tabel 8. Hasil Validasi Dosen Ahli Materi

\begin{tabular}{|c|c|c|}
\hline Aspek & Rerata & Kategori \\
\hline \multirow{2}{*}{ Isi Materi } & \multirow{2}{*}{ 3,34 } & Sangat \\
\hline & & Layak \\
\hline Pembelajaran & 3,20 & Layak \\
\hline \multirow{2}{*}{ Rerata } & \multirow{2}{*}{3,23} & Sangat \\
\hline & & Layak \\
\hline
\end{tabular}

Berdasarkan hasil penilaian yang dilakukan oleh ahli materi diketahui bahwa untuk aspek isi materi mendapatkan skor 3,34 yang berarti masuk pada kriteria sangat layak dengan presentase 83,34\%, untuk aspek pembelajaran mendapatkan skor 3,20 yang termasuk dalam kriteria layak dengan presentase $80 \%$. Sehingga secara keseluruhan kualitas materi ajar Gambar Teknik Manufaktur masuk pada kriteria sangat layak dengan skor rerata 3,23 dan presentase $82 \%$.

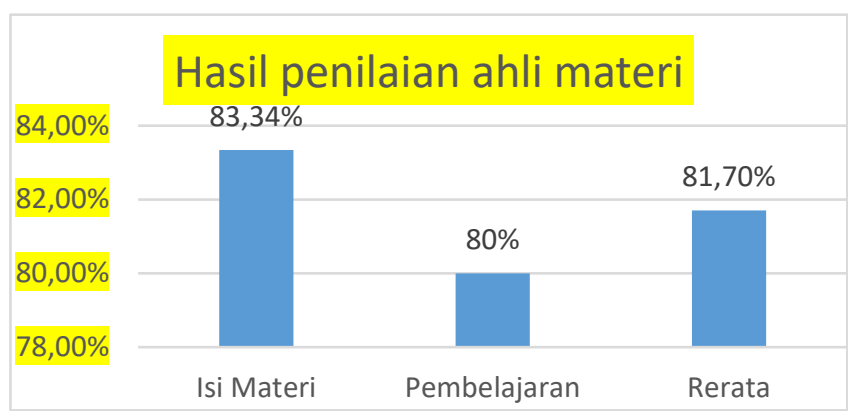

Gambar 6. Hasil validasi ahli materi

Hasil validasi dari dosen ahli media dapat dilihat pada Tabel 9. 
Tabel 9. Hasil Validasi Dosen Ahli Media

\begin{tabular}{|c|c|c|c|}
\hline Media & Aspek & $\begin{array}{l}\text { Nilai } \\
\text { Akhir }\end{array}$ & Kategori \\
\hline \multirow{3}{*}{ FlipBuilder } & $\begin{array}{c}\text { Tampilan } \\
\text { media }\end{array}$ & 3,25 & $\begin{array}{l}\text { Sangat } \\
\text { Layak }\end{array}$ \\
\hline & Pemograman & 3,34 & $\begin{array}{l}\text { Sangat } \\
\text { Layak }\end{array}$ \\
\hline & $\begin{array}{c}\text { Kelengkapan } \\
\text { media }\end{array}$ & 3,34 & $\begin{array}{c}\text { Sangat } \\
\text { Layak }\end{array}$ \\
\hline \multirow{3}{*}{ Edmodo } & $\begin{array}{c}\text { Pemilihan } \\
\text { media }\end{array}$ & 3,5 & $\begin{array}{c}\text { Sangat } \\
\text { Layak }\end{array}$ \\
\hline & Pemograman & 3,5 & $\begin{array}{c}\text { Sangat } \\
\text { Layak }\end{array}$ \\
\hline & Rerata & 3,38 & $\begin{array}{c}\text { Sangat } \\
\text { Layak }\end{array}$ \\
\hline
\end{tabular}

Hasil penilaian media pembelajaran yang digunakan untuk mendukung materi ajar Gambar Teknik Manufaktur oleh ahli media menunjukan untuk media pembelajaran flip builder pada aspek tampilan media, pemograman dan kelengkaan media mendapat kategiri sangat layak. Media pembelajaran Edmodo yang digunakan, pada aspek pemilihan media dan pemograman juga mendaptkan kriteria sangat layak, dari data diatas media pembelajaran mendapatkan skor rerata 3,38 yang termasuk dalam kriteria sangat layak, denganpresentas 83,65\%.

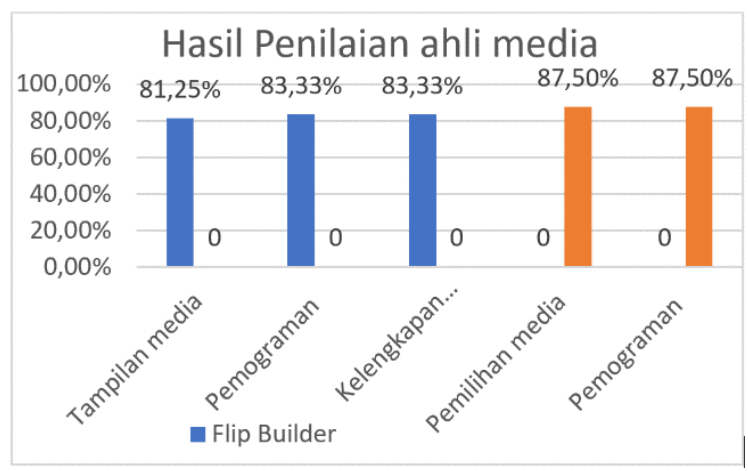

Gambar 7. Hasil validasi ahli media

Hasil validasi dari guru ahli materi dapat dilihat pada Tabel 10.
Tabel 10. Hasil Validasi Guru Ahli Materi

\begin{tabular}{ccc}
\hline Aspek & Nilai Akhir & Kategori \\
\hline Isi & 3 & Layak \\
Bahasa & 3 & Layak \\
Sajian & 3,2 & Layak \\
Kegrafikan & 3 & Layak \\
\hline Rerata & 3,04 & Layak \\
\hline
\end{tabular}

Kegiatan terakhir pada tahap pengembangan (development) adalah pengujian materi ajar kepada peserta didik. Uji cobalapangan dilakukan pada 30 pesertaa didik. Hasil menujukan bahwa aspek isi materi mendapatkanskor 4,27 dan aspek pembelajaran 4,2. Secara keseluruhan, hasil uji coba membperoleh nilai rata-rata 4,215 yang berarti masuk dalam kriteria sangat layak, dengan presentase $83,105 \%$.

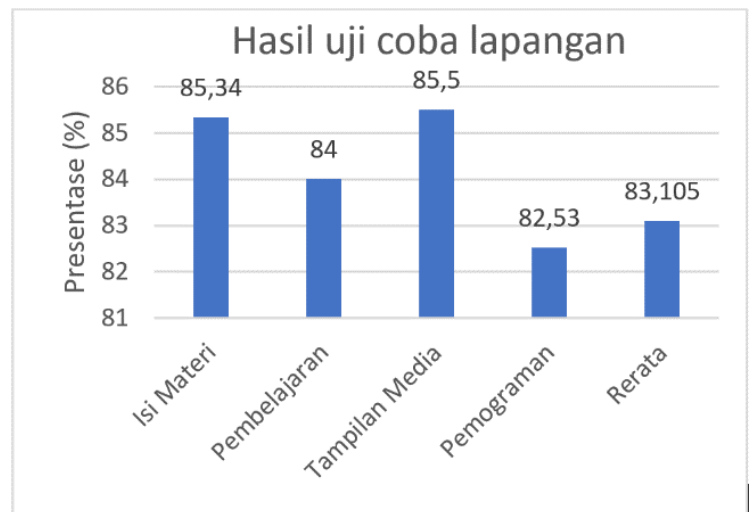

Gambar 8. Hasil uji coba lapangan

Tahapan terakhir yang dilakukan adalah disseminate atau penyebarluasan. Pada tahap ini diakukan penyebaran hasil penelitian berupa materi ajar dalam bentuk file dan alamat/link untuk membuka media pembelajaran. Penyebaran dilakukan secara terbatas dan dikirim ke Guru Pemesinan SMK N 2 Yogyakarta untuk dapat digunakan dalam proses pembelajaran di kelas maupun secara mandiri oleh peserta didik. 


\section{SIMPULAN}

Hasil penelitian dan pengembangan yang telah dilakukan adalah produk materi ajar berbantuan Edmodo pada mata pelajaran Gambar Teknik Mnufaktur untuk SMK yang dikembangkan dengan aplikasi tambahan Flip Builder untuk membuat tampilan materi ajar lebih menarik. Materi yang dibuat dalam pembelajaran Gambar Teknik Manufaktur terdiri dari 5 kegiatan pembelajaran yang embahas tentang penggunaan aplikas CAD, yaitu Autodesk Inventor Profesional 2017. Materi ajar terbsebut dikembangkan dengan beberapa langkah, yaitu: (a) mendefinisikan kebutuhan dan analisis awal, analisis kosep materi dan analisis tujuan pembelajaran yang akan dicapai. (b) Melakukan perancangan dengan menyusun parameter penilaian, pemilihan format, pemilihan media, pembuatan rancangan awal sehingga dihasilkan materi ajar sebagai prototipe. (c) Melakukan pengembangandengan validasi produk oleh ahli materi dan ahli media yang diikuti revisi berdasarkan saran dan masukan dar para ahli, dilanjutkan dengan uji coba lapangan untuk mendapatkan respon dar peserta didik sebagai pengguna materi ajar. (d) melakukan penyebaran materi ajar dengan cara membagikan hasil pengembangan materi ajar kepada guru di SMK N 2 Yogyakarta.

Validasi dari dosen ahli materi mendapat nilai rerata 3,23 dengan presentase 82\% yang termasuk dalam kategori sangat layak. Validasi dari dosen ahli media mendapat nilai rerata 3,38 dengan presentase $83,65 \%$ yang trasuk kedalam kategori sangat layak.. Penilaian dari siswa sebagai pengguna materi ajar mendapat nilai rata-rata 4,215 dengan presentase 83,105\% yang termasuk kedalam kategori sangat layak.

Saran yang dapat disampaikan bahwa perlu pengembangan lebih lanjut terhadap materi adar diantarannya menggunakan animasi dalam bentuk 3D untuk mengilustrasikan materi yang ada. Untuk penelitian lebih lanjut dapat dilakukan uji coba lapangan secara langsung sehingga siswa lebih engerti mengenai materi dan media yang digunakan. Meskipun materi ajar ini masuk pada kriteria sangat layak, materi ajar ini belum sepenuhnya dapat digunakan untuk pembelajaran mandiri, untuk itu guru diharapkan tetap mendampingi siswa untuk membantu siswa yang merasa kesulitan supaya mencapai tujuan pembelajaran yang optimal.

\section{DAFTAR RUJUKAN}

Febrianto Amri R, dan Yatin Ngadiyono. (2017). Pengembangan Model Pembelajaran Berbasis CTL Untuk Meningkatkan Kompetensi Menggambar Berbantuan Komputer (CAD) Siswa SMK. Jurnal Dinamika Vokasional Teknik Mesin, 2(1), 73-81.

Ibrahim, R dan Nana Syaodih. 2002. Perencanaan Pengajaran. Jakarta: Rineka Cipta.

International Symposium on Open, Distance and E-Learning (ISODEL). (2018). Pendidikan 4.0 untuk Indonesia. Diperoleh 15 November 2018 dari https://mediaindonesia.com/read/detai 1/202806-isodel-2018-di-balihasilkan-20-rekomendasi. 
Kemendikbud. (2013). Peraturan Mentri Pendidikan dan Kebudayaan Republik Nomor 65, tahun 2013, tentang Standart Proses Pendidikan Dasar dan Menengah.

Paryanto, dan Asnawi. (2012). Penerapan Metode Tutorial untuk Meningkatkan Kompetensi Teori Pemesinan Sebagai Penunjang Pelaksanaan Praktik Pemesinan, di Universitas Negeri Yogyakarta. Yogyakarta. Prosiding, Seminar Nasional Pendidikan Teknik Mesin yang diselenggarakan oleh FT UNY, tanggal 2 Juni 2012. Yogyakarta: Universitas Negeri Yogyakarta.

Pemerintah Indonesia. (2003). UndangUndang Nomor 20 Tahun 2003 Tentang Sistem Pendidikan Nasional.
Lembaran Negara RI Tahun 2003 Nomor 4301. Jakarta: Sekretariat Negara Republik Indonesia.

Suroto. (2015). Penggunaan Model Pembelajaran Explicit Instruction dengan Trainer PLC untuk Meningkatkan Prestasi Belajar Merakit Sistem PLC. Jurnal Pendidikan Teknologi dan Kejuruan, 22(3), 316323.

Thiagarajan, Sivasailam. (1974). Instructional Develoment for Training Teachers of Exceptional Children. Indiana: Indiana University. 